\title{
Joanna Brzezińska
}

University of Wrocław, Poland

ORCID: 0000-0002-5030-3363

joanna.brzezinska@uwr.edu.pl

\section{Women as Perpetrators of Crimes in Poland: An Analysis from a Statistical Perspective*}

\author{
Kobiety jako sprawczynie przestępstw w Polsce. \\ Analiza z perspektywy statystyk
}

\begin{abstract}
The article aims to determine the trends in the phenomenon of female delinquency in Poland in the years 2003-2018. To this end, on the basis of statistical data obtained from the Ministry of Justice: 1) the total number of convictions of female perpetrators during the analysed period was determined; 2) the categories of crimes which resulted in the highest level of convictions of female perpetrators were identified; 3 ) the types of crimes which dominated the criminal activity of women were analysed; 4) it was determined whether the level of female aggression accompanying the implementation of crimes increases. In the course of the research, several remarks were formulated, of which three findings remain the most important: 1) women commit crimes analogous to those of men (the absence of such prohibited acts which they would not commit); 2) infanticide, which was considered to be the most symptomatic female crime in view of the incidence of convictions under Article 149 of the Polish Criminal Code, loses its character; 3 ) the crime which dominates from the perspective of statistical research on the number of convictions of female perpetrators is currently fraud.
\end{abstract}

Keywords: phenomenon of female delinquency; number of convictions of female perpetrators; infanticide; fraud

CORRESPONDENCE ADDRESS: Joanna Brzezińska, PhD, Assistant Professor, University of Wrocław, Faculty of Law, Administration and Economics, Uniwersytecka 22/26, 50-145 Wrocław, Poland.

* The article is the result of research carried out as part of the research project no. DEC 2015/19/B/HS5/03042, financed by the National Centre of Science. 


\section{INTRODUCTION}

Studies of the problem of female delinquency undertaken in the science of criminology for several decades have shown that it is stereotypically perceived ${ }^{1}$ as an atypically negative phenomenon, and the only issue that has been established so far is that female delinquency differs from male delinquency in general in terms of frequency, which remains low. ${ }^{2}$ Whatever the scope and context of the analyses carried out, it is clear from them that none of the European and non-European societies currently have an excess of female perpetrators over male perpetrators in their crime statistics. ${ }^{3}$

Criminological analyses of the participation of women in the total number of perpetrators carried out in Poland ${ }^{4}$ allow us to observe that the evolution of the phenomenon under investigation has been strongly emphasised. ${ }^{5}$ The statistics which reveal the level of convictions of women over the last few decades show that while in the 1950s there were 23.6 women out of 100 convictions, in the 1990 s there were only 6 , currently, we should note a renewed, regular increase. ${ }^{6}$ Such a serious remodelling of the frequency of convictions of women has been explained on

${ }^{1}$ Cf. E. Mandal, Kobiecość i męskość. Popularne opinie a badania naukowe, Warszawa 2003.

2 As B. Hołyst points out, in Poland female delinquency remains at $10 \%$ of all crimes, but in Belgium, for example, it is already $20 \%$, and in the USA $-15 \%$. The level of civilisational development achieved by individual states is therefore not insignificant in the context of the category of delinquency under consideration. Cf. P. Otto, Pteć piękna także łamie prawo. Odsetek kobiet wśród sprawców przestępstw rośnie, 8.01.2019, https://prawo.gazetaprawna.pl/galerie/1390926,duze-zdjecie,2,odsetek-kobiet-wsrod-sprawcow-przestepstw-rosnie.html [access: 19.11.2020].

3 The phenomenon of the lack of proportion between women and men in criminal statistics is described as a "gender gap in crime". See E. Carrabine, P. Iganski, M. Lee, Criminology: A Sociological Introduction, New York 2004, p. 88; J.T. Walker, S. Maddan, Understanding Statistics for the Social Sciences, Criminal Justice, and Criminology, London 2013, p. 99; O. Choy, A. Raine, P.H. Venables, D.P. Farrington, Explaining the gender gap in crime: The role of heart rate, "Criminology" 2017, vol. 55(2); D. Steffensmeier, E. Allan, Gender and Crime: Toward a Gendered Theory of Female Offending, "Annual Review of Sociology" 1996, vol. 22, pp. 459-487.

${ }^{4}$ J. Stojer-Polańska, Ciemna strona kobiet, www.swps.pl/strefa-psyche/blog/relacje/ 16043-ciemna-strona-kobiet [access: 19.11.2020].

${ }^{5}$ B. Hołyst (Kryminologia, Warszawa 2004, p. 226) indicates that "a modern woman not only seeks equality before the law and in her profession, but actually wants to free herself from male domination and even fights for her social rights. This course of events has a very significant impact on changes in the nature of female delinquency".

${ }^{6}$ J. Błachut, A. Gaberle, K. Krajewski, Kryminologia, Gdańsk 2004; J. Błachut, Płeć a przestępczość, [in:] Nauka wobec przestępczości. Ksiega ku czci Prof. T. Hanauska, eds. J. Błachut, M. Szewczyk, J. Wójcikiewicz, Kraków 2001, p. 162 ff.; eadem, Kobiety recydywistki w świetle badań kryminologicznych, Wrocław 1981; E. Zielińska, Kobiety $i$ wymiar sprawiedliwości, „Prawo i Płeć” 2001, no. 1, pp. 5-11; T. Kolarczyk, J.R. Kubiak, P. Wierzbicki, Przestępczość kobiet. Aspekty kryminologiczne i penitencjarne, Warszawa 1984, pp. 70-80. 
several levels. ${ }^{7}$ Its causes were seen in radical shifts in socio-economical aetiology (political changes), in professional activation of the female gender (employment), ${ }^{8}$ and moreover in major changes in the structure of social roles (social conditions). ${ }^{9}$ Meanwhile, the increase in the proportion of women in crime statistics has even been given the term "criminal emancipation". ${ }^{10}$ At the same time, it should be stressed that the interest that accompanies female delinquency intensifies different reactions, on the one hand, arouses public interest, linked to negative assessments of the phenomenon under analysis, ${ }^{11}$ which is in clear contradiction with the stereotype of a gentle, submissive and non-violent woman, ${ }^{12}$ and, on the other, is associated with a desire to clarify and interpret the direction of her evolution. ${ }^{13}$

The main objective of this study remains the analysis of statistical data, obtained from the Ministry of Justice, on the image of female delinquency from the perspective of the trends that it showed in the years 2003-2018. However, the most important assumption of the following analysis remains to verify, on the basis of the data analysed, the validity of the concept, concerning three issues: 1) the determination of whether there are indeed categories of crimes that women do not commit; 2) the verification of whether aggression by women is increasing; ${ }^{14}$ 3 ) the determination of which crime remains currently the most symptomatic of female criminal activity.

${ }^{7}$ P. Otto, op. cit.

${ }^{8}$ A. Moir, D. Jessel, Pteć mózgu. O prawdziwej różnicy między mężczyzną a kobieta, Warszawa 2017, p. 17 ff.; S. Szatner, Socjologia kobiety, Warszawa 1948, p. 206.

${ }^{9}$ F. Adler, The interaction between women's emancipations and female criminality: A cross-cultural perspective, [in:] The Criminology of Deviant Women, eds. F. Adler, R.J. Simon, Boston 1979, pp. 407-418.

${ }_{10}$ Z. Majchrzyk, Kiedy kobieta zabija. Motywy, osobowość, relacja sprawca-ofiara, strategie obronne, Warszawa 2009, p. 35.

11 A. Bałandynowicz, Przestępczość kobiet w środowisku miejskim, „Prokuratura i Prawo”2002, no. 10.

${ }^{12}$ L. Tyszkiewicz, Kryminologia. Zarys systemu, Katowice 1986, pp. 186-189.

${ }_{13}$ M. Grzyb, E. Habzda-Siwek, Pteć a przestępczość. O problemie dysproporcji płci wśród sprawców przestępstw z użyciem przemocy, „Archiwum Kryminologii” 2013, vol. 35, pp. 96-97.

${ }^{14}$ According to analyses carried out by M. Przybysz-Zaremba, "violence used by women against men is almost equal to that used by men". In turn, research carried out by M. Makara-Studzińska, A. Grzywa and R. Turek shows that women are more likely to use psychological aggression and direct it primarily towards children, due to the fact that they are victims with less resistance than men. See M. Przybysz-Zaremba, (Prze)moc kobiet - (nie)moc mężczyzn, „Szkice Humanistyczne Olsztyńskiej Szkoły Wyższej” 2008, vol. 8, p. 12; M. Makara-Studzińska, A. Grzywa, R. Turek, Kobiece oblicza stosowania przemocy, „Postępy Psychiatrii i Neurologii” 2005, no. 14, p. 195 ff.; R.J.A. McQuigg, Potential problems for the effectiveness of international human rights law as regards domestic violence, [in:] International Human Rights Law and Domestic Violence: The Effectiveness of International Human Rights Law, ed. R.J.A. McQuigg, Oxford - New York 2011, p. 13. 


\section{ANALYSIS OF STATISTICAL DATA}

The phenomenon of female delinquency can be analysed from the perspective of different factors, but undoubtedly one of the most important ones remains the identification of trends in women's behaviour that are relevant from a criminal law perspective. Outlining this research perspective requires the compilation of varying range of statistical data with the aim of) determination of the total number of female convictions, identification of a catalogue of crimes committed by female sex, and indication of categories of crimes with the highest degree of social harm, as well as listing of those types of crimes which women commit with the highest degree of frequency. In view of the fact that statistics on female delinquency from the Ministry of Justice for the period 2003-2018 have been made available, the phenomenon under examination is analysed within the indicated period of time, taking into account the criteria set out above.

Total number of women sentenced between 2003 and 2018

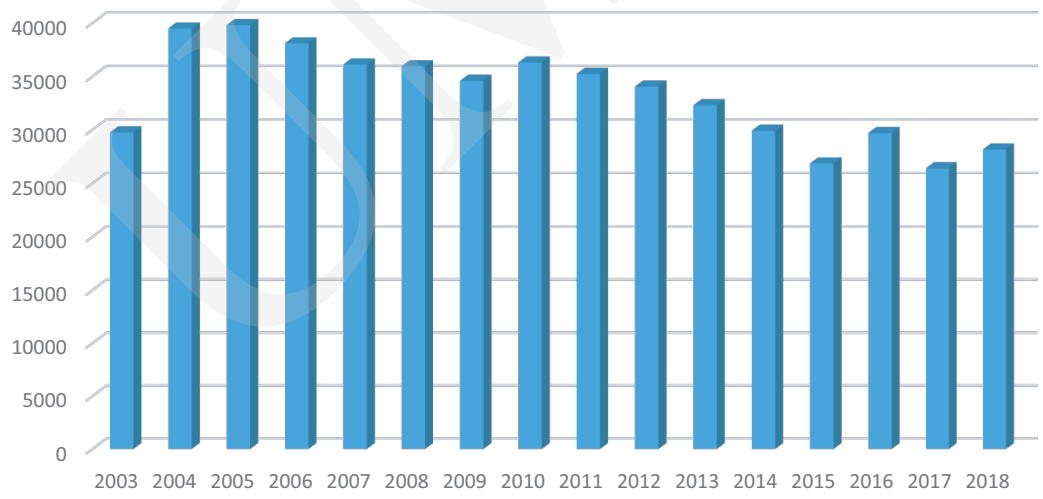

Figure 1.

Source: own elaboration based on statistical data obtained from the Ministry of Justice.

The analysis of Figure 1 leads to the conclusion that the number of women sentenced in Poland between 2003 and 2018 ranged from 29,753 in 2003 to 39,796 in 2005. Taking into account the 16-year research period (2003-2018), it should be noted that there was a discrepancy between the minimum and maximum levels of convictions of 10,000 cases. Moreover, in 2003 which marked the beginning of the research period and 2018 which closed the analysis period, the level of convictions was at a comparable level (nearly 29,000 convictions). At the same time, since 2004, there has been a strong trend towards an increase in convictions of female perpetrators, particularly between 2004 and 2005 and in 2010. Moreover, it should be noted that in the years 2006-2009 and 2010-2015, the number of convictions, 
originally at a high level, was regularly reduced (in the first period it ranged from 39,484 to 34,577 , while in the second period it ranged from 36,296 to 26,846 ), reaching its lowest level in 2015. Focusing on identifying the overall trend in the number of women's convictions between 2003 and 2018, it should be noted that it has experienced a slow, heterogeneous downward trend with periods of slight increase (2004-2005 and 2010).

\section{Total number of women sentenced between} 1980 and 1996

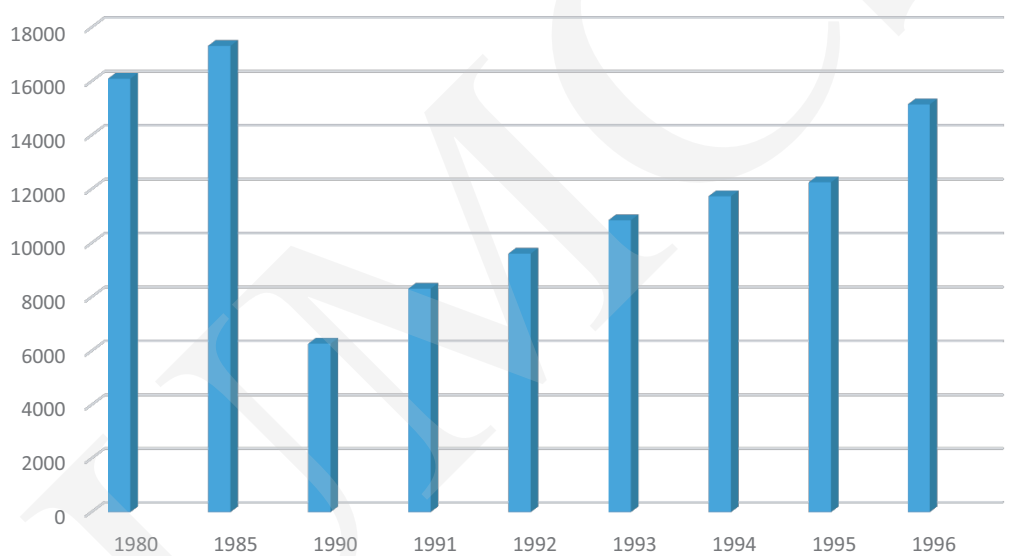

Figure 2 .

Source: J. Błachut, A. Gaberle, K. Krajewski, Kryminologia, Gdańsk 2006, p. 221.

For comparison, the level of female convictions, which occurred between 2003 and 2018, is present in Figure 2, which shows their level between 1980 and 1996. Given that the compilation aimed to compare the scale of the phenomenon of female convictions, similar research periods were taken into account (16 years), although for the second research period the data presented remain slightly less precise (between 1980 and 1990 the level of convictions is presented in five-year intervals, while between 1990 and 1996 the level of convictions is determined for each year separately). However, there are two main conclusions from this compilation. Firstly, the total number of women convicted between 1980 and 1996 remained substantially lower than between 2003 and 2018. However, the data contained in Figure 2 shows that the maximum level of convictions in the 1980-1996 research period was in 1985 and exceeded 17,000 cases, while, as shown in Figure 1, the maximum level of convictions in the 2003-2018 research period was in 2005, reaching nearly 40,000 convictions. Moreover, in the first of these research periods, between 1985 and 1990, there was a significant drop in the number of convictions, because while in 1985 they reached over 17,000 cases, in 1990 they exceeded only 6,000. In addition, it should be noted 
that since 1990, a trend of a slow, regular increase in the number of women convicted began, oscillating at 60\% (from 6,000 in 1990 to 15,000 in 1996).

The greatest discrepancy in the number of convictions of women in the analysed periods concerned their minimum level, which in the first research period 1980-1996 amounted to slightly over 6,000 cases (in 1990), while in the second research period (2003-2018) it amounted to nearly 27,000 cases in 2015 (discrepancy of over 20,000 convictions).

Interesting insights emerge as a result of the analysis of Figures 3 and 4, which are an exemplification of the breakdown of the different categories of crimes committed by women between 2003 and 2018. First of all, it should be stated that there is one category of crime with clearly the highest frequency during the entire research period, namely, those related to attacks on property. The maximum level of these crimes was recorded in 2004, when the number of convictions was 17,495, and the lowest in 2015, when 12,534 convictions were recorded. From 2012 onwards, a slow downward trend can be observed in the category of crimes under consideration.

Another group of crimes where women show a significant (although incomparably lower than in the case of attacks on property) degree of criminal activity are crimes against traffic safety. ${ }^{15}$ As can be seen from Figures 3 and 4, in the years 2003-2012, in the category of crimes under examination, a regular increase was observed from 3,143 cases in 2003 to 5,493 in 2012. However, after a period of upward trend, they fell to 3,386 convictions in 2018.

The third category of crimes, from the perspective of frequency, committed by women was crimes against the authenticity of documents during the research period under consideration. It should be noted that between 2003 and 2009, they remained a category with an upward trend (the maximum level was 4,782 cases in 2005), but from 2010 onwards, the number of convictions began to fall, and in 2018 it reached 1,728 .

A different trend, in turn, can be observed in the category of crimes against business trading, while between 2003 and 2004 there was a slightly higher level of convictions under this category of crimes (2,950 and 3,200 respectively), followed by a stable frequency between 2005 and 2018 (an average of 2,500 convictions per year). The lowest level of crimes among the analysed categories is shown by convictions for crimes against sexual freedom and decency, which in the analysed period of time were committed by women several dozen times on average per year (between 45 convictions in 2003 and 96 convictions in 2005).

${ }^{15}$ E. Jurgielewicz-Delegacz, Wypadki w komunikacji powodowane przez kobiety będace kierowcami-ujęcie kryminologiczne, [in:] Przestępczość kobiet. Wybrane aspekty, ed. J. Brzezińska, Warszawa 2017, p. $224 \mathrm{ff}$. 
Pobrane z czasopisma Studia Iuridica Lublinensia http://studiaiuridica.umes.pl Data: 26/04/2023 15:50:08

Women as Perpetrators of Crimes in Poland: An Analysis from a Statistical Perspective

The level of convictions of women in the category of crimes against the family and guardianship ${ }^{16}$ is also interesting, and it was twice as high as the average in the period under study: 1,044 convictions in 2004 and 2,222 in 2018 respectively. It should be noted, however, that during the period under study, with the exceptions indicated, the level of convictions for crimes against the family and guardianship committed by women was at a relatively comparable level of several hundred cases (an average of nearly 800 per year). ${ }^{17}$

\section{Categories of crimes most frequently committed by women in the years 2003-2010}

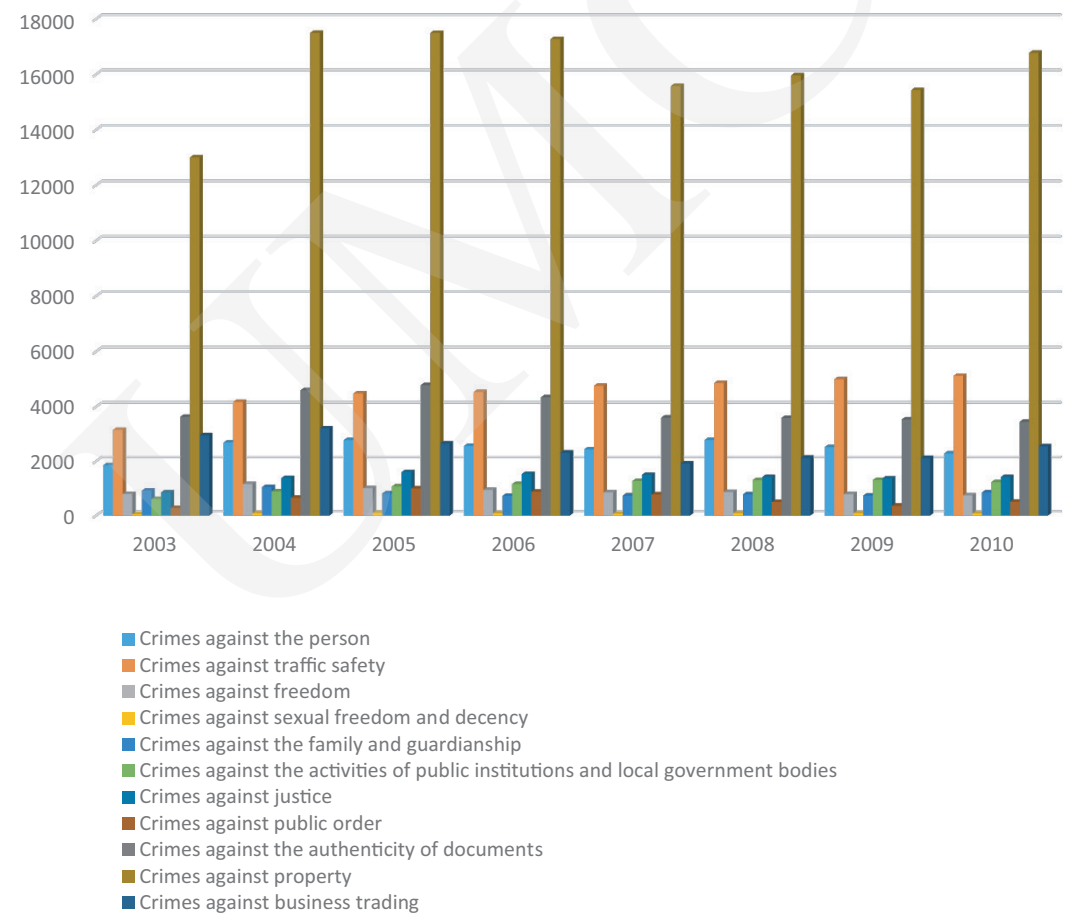

Figure 3.

Source: own elaboration based on statistical data obtained from the Ministry of Justice.

${ }^{16}$ M. Cabalski, Przemoc stosowana przez kobiety, Kraków 2017, p. 313 ff.; S. Mielnik, Mężczyzna jako ofiara przemocy w rodzinie, [in:] Mężczyzna w kryzysie. Sytuacja prawna mężczyzn przeżywających problemy rodzinne, ed. R. Kucharski, Warszawa 2008; H. Kołakowska-Przełomiec, Przemoc w rodzinie, „Ruch Prawniczy, Ekonomiczny i Socjologiczny” 1985, no. 1.

${ }_{17}$ Diagnoza zjawiska przemocy w rodzinie w Polsce wobec kobiet i wobec mężczyzn. Cześć I: Raport z badań ogólnopolskich, https://archiwum.mpips.gov.pl/gfx/mpips/userfiles/_public/1-2010_\%20 Raport-ogolnopolski_K-M_01-03-11.pdf [access: 10.10.2020]. 
Pobrane z czasopisma Studia Iuridica Lublinensia http://studiaiuridica.umcs.pl Data: 26/04/2023 15:50:08

Undoubtedly, the most socially harmful crimes among the categories examined are those aimed at harming human life and health. When analysing the frequency of convictions, it should be noted that their level remained stable during the period under examination, with an average of 2,500 convictions per year in the category of crimes in question between 2004 and 2010, while between 2011 and 2018, it was close to 2,000 cases per year on average. The lowest level was in 2003 with 1,848 convictions, while the highest was in 2005 with 2,773 cases. Thus, a slight downward trend emerged in the period considered between 2003 and 2018.

\section{Categories of crimes most frequently committed by women in} the years 2011-2018

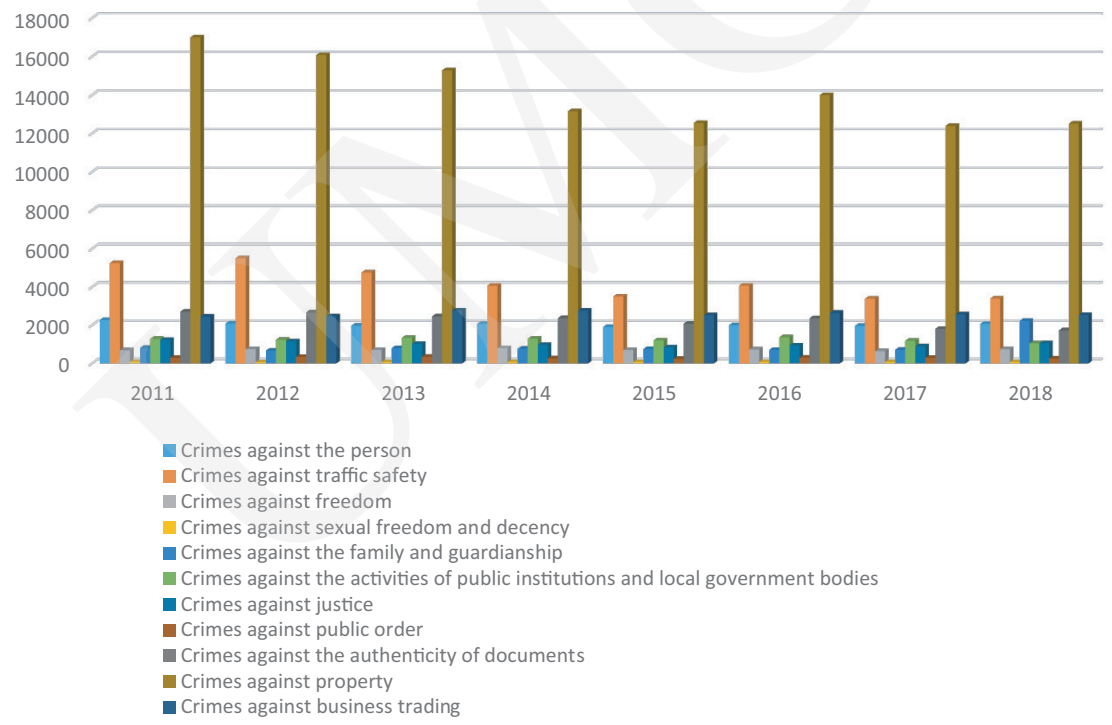

Figure 4.

Source: own elaboration based on statistical data obtained from the Ministry of Justice.

Figure 5 presents a summary of the frequency of convictions in relation to selected types of crimes against the person, committed by female perpetrators between 2003 and 2018. From the data presented, it is clear that the prohibited act, with the dominant number of convictions in the analysed category of crimes, remained a brawl and beatings (Article 158 of the Polish Criminal Code). ${ }^{18}$ In the

18 Cf., i.a., M.D. Pełka-Sługocka, L. Sługocki, Przestęstwa przy użyciu przemocy popetnione przez kobiety w Polsce, „Studia Kryminologiczne, Kryminalistyczne i Penitencjarne” 1983, vol. 13, pp. 119-121; M. Cabalski, Ogólne problemy stosowania przemocy przez kobiety, „Studia Prawnicze i Administracyjne Wyższej Szkoły Menedżerskiej w Warszawie” 2011, no. 1; K. Krajewski, O pojęciu 
years 2004-2007, several hundred cases of convictions under Article 158 of the Polish Criminal Code were recorded among women, with the highest level between 2004 and 2005 (650 and 623 cases respectively). At present, although their level of convictions is still quite high, it does not exceed 300 cases per year on average, so there is a slow downward trend.

Another type of crime committed by women that shows a high level of convicted persons is a crime of medium and slight damage to health (Article 157 of the Polish Criminal Code). It is worth pointing out that, according to the list shown in Figure 5, women committed several hundred cases of the type of prohibited act analysed, with the level of convictions being a minimum of 293 cases in 2007 and a maximum of 436 in 2018. However, on a yearly average, their participation in the type of crimes analysed was associated with convictions of almost 380 cases.

The third most common type of crimes committed by female perpetrators in the category of crimes against the person remains exposing a human being to a danger (Article 160 of the Polish Criminal Code). In the case of the prohibited act in question, a clear upward trend in convictions was noted between 2003 and 2010, reaching its optimum in 2008 of 488 cases. Since 2011, however, a decrease in the frequency of fulfilling the features of Article 160 of the Polish Criminal Code by women became apparent, and the level of convictions ranged from 230 to 290 cases (2011-2018).

The list analysed in relation to the crime of murder in the basic type and its modified types is extremely interesting. ${ }^{19}$ In the case of the basic type, on a yearly average, several dozen convictions for homicide ${ }^{20}$ have to be recorded, with the highest level between 2003 and 2004, with more than 70 cases, followed by a slight decrease. In the years 2005-2015, it was close to 60 convictions, and it further decreased slightly to nearly 40 cases in 2016-2017 and 29 in 2018.

In the period under consideration, the types of aggravated murders occurred incidentally and were connected with the maximum level of convictions of 5 cases, occurring in the years 2005-2006. The same frequency of convictions was shown in

przemocy w kryminologii, „Studia Kryminologiczne, Kryminalistyczne i Penitencjarne” 1988, no. 19, p. $78 \mathrm{ff}$.

${ }_{19}$ M. Budyn-Kulik, Zabójstwo tyrana domowego. Studium prawnokarne i wiktymologiczne, Lublin 2005, p. 27 ff.; M. Cabalski, Przemoc ..., p. 389 ff.; Z. Majchrzyk, Kiedy kobieta zabija..., p. 212; B. Hołyst, Psychologia kryminalistyczna, Warszawa 2006, pp. 408-422.

${ }^{20}$ Z. Majchrzyk, Kiedy kobieta zabija ..., p. 212 ff.; idem, Zabójczynie i zabójcy, Warszawa 2008, p. 87 ff.; T. Jaśkiewicz-Obydzińska, E. Wach, Sprawczynie zabójstw, [in:] Zabójcy i ich ofiary. Psychologiczne podstawy profilowania nieznanych sprawców zabójstw, eds. J.K. Gierowski, T. Jaśkiewicz-Obydzińska, Kraków 2002, pp. 69-87; A. Florkowski, S. Telesiński, Ocena psychopatologiczna sprawców zabójstw związanych z konfliktami w rodzinie, [in:] Stany afektywne w opiniowaniu sądowym psychiatryczno-psychologicznym, eds. Z. Majchrzyk, T. Gordon, E. Milewska, Warszawa 1991, p. 122. 
Pobrane z czasopisma Studia Iuridica Lublinensia http://studiaiuridica.umcs.pl Data: 26/04/2023 15:50:08

the analysed period by the crime of mitigated murder, committed under the influence of strong agitation justified by the circumstances (maximum 9 convictions in 2003).

In turn, an extremely interesting trend can be observed with regard to the crime of infanticide. ${ }^{21}$ In the years 2003-2009, women committed several cases of this type of mitigated crime, while in the years 2010-2018 (especially since 2013) its frequency was further reduced and showed an incidental character, in 2017 no case of conviction under Article 149 of the Polish Criminal Code was recorded ${ }^{22}$. It seems, therefore, pertinent to say that infanticide which until now has been regarded as an exclusively female crime, taking into account the statistics presented on the related convictions, has lost this status.

The frequency of convictions concerning: unintentional causing of death (Article 155 of the Polish Criminal Code) and failure to provide assistance (Article 162 of the Polish Criminal Code) developed at a comparable low level (maximum 27 and 29 convictions respectively, minimum 12 and 11 convictions) during the analysed period.

\section{Crimes against the person committed by women between \\ 2003 and 2018}

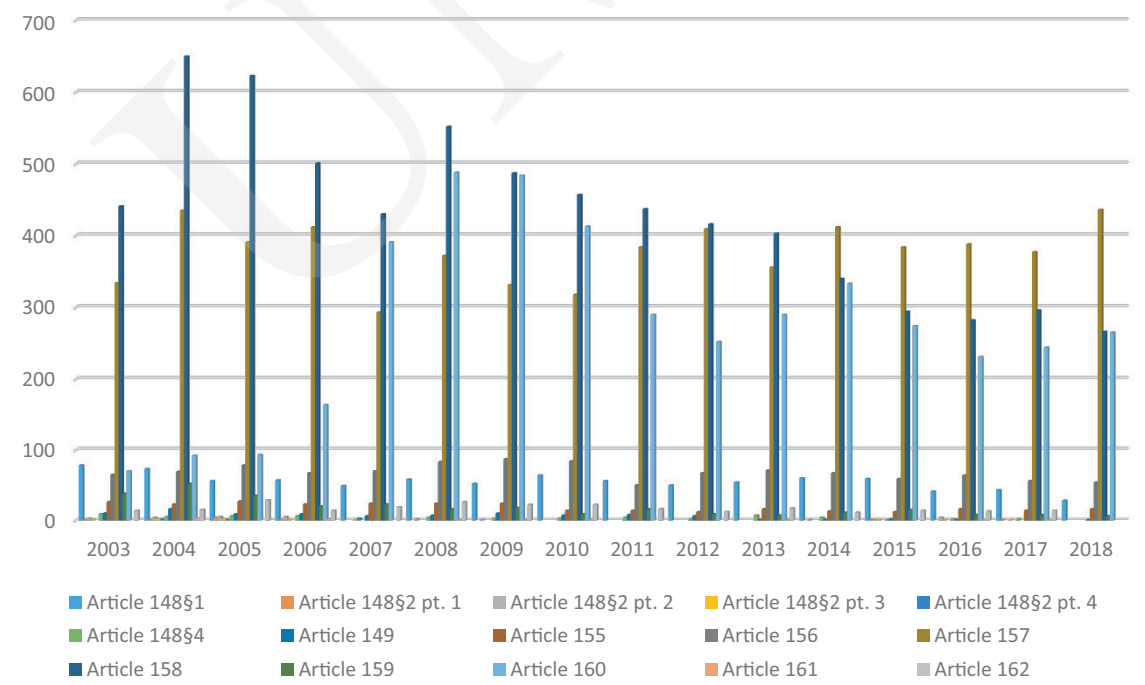

Figure 5 .

Source: own elaboration based onstatistical data obtained from the Ministry of Justice.

${ }^{21}$ J. Brzezińska, Dzieciobójstwo. Aspekty prawne i etyczne, Warszawa 2013, p. $361 \mathrm{ff}$.

22 Ibidem; eadem, $O$ dzieciobójstwie z perspektywy statystyk, „Nowa Kodyfikacja Prawa Karnego" 2010, no. 26, pp. 32-34; eadem, O niektórych kontrowersjach wokót znamion przestęstwa dzieciobójstwa, „Ius Novum” 2012, no. 2, pp. 37-60. 
Statistical data on the frequency of convictions of women for particular types of crimes against property are presented in Figure 6. Closer analysis of the list proves that three types of crimes dominated in the examined category of crimes: fraud (Article 286 of the Polish Criminal Code), theft (Article 278 of the Polish Criminal Code) and misappropriation (Article 284 of the Polish Criminal Code). Fraud, in turn, was clearly dominant in this group of crimes. Looking at the period under examination, it can be concluded that the crime in question showed an alternating upward and downward trend in the number of convictions. The increase in the level of convictions for the crime of fraud committed by women took place in the years 2003-2005, 2008-2011, 2013-2016, reaching a maximum of 8,382 cases, while a downward trend in the number of convictions was observed in the years: 2006-2007, 2012-2014 and 2017-2018, with the lowest level in 2003, when 5,891 cases were recorded.

The second prohibited act whose level of convictions in the category of crimes against property remains high is theft of the basic type. It should be noted, however, that the frequency of convictions under Article 278 of the Polish Criminal Code is at a lower level than in the case of a fraudulent crime. For example, the two upward trends observed in the period under consideration were in the years: 2003-2006 and 2008-2010, however, the maximum level of convictions for theft reached 5,804 cases in 2011. However, the fall in the number of convictions for theft among women was noticeable in the years: 2007-2008 and 2012-2015, with the lowest level in 2015 reaching 3,597 cases. The downward trend is currently continuing.

The last most numerous (although much less abundant than the previous two) type of crimes against property remains misappropriation. The frequency of convictions on the basis of the type of crime in question among women reaches a yearly average of more than 1,000 cases, with a maximum of 1,698 in 2005 and a minimum of 1,004 in 2018, although it should be noted that between 2003 and 2004, the frequency of convictions for the crime increased, at present the level remains moderate and shows a stabilising trend (2014-2018).

Then, at a level of several hundred convictions per year, women commit the following crimes: burglary (500 cases in average per year; maximum 659 cases in 2004), destruction or damage to someone else's property (330 cases per year on average; maximum 398 crimes in 2012) and robbery (290 cases per year on average; maximum 493 crimes in 2004).

The last of the categories of crimes that show a high frequency of convictions of women are crimes against traffic safety (Figure 7). Two of them are predominant in the analysed category of crimes: driving a motor vehicle under the influence of alcohol or under the influence of a narcotic drug (Article 178a of the Polish Criminal Code) and causing a traffic accident (Article 177 of the Polish Criminal Code). In the case of the first crime, the upward trend in the number of convictions was long-lasting and manifested itself between 2003 and 2012, as well as between 2015 
Pobrane z czasopisma Studia Iuridica Lublinensia http://studiaiuridica.umcs.pl

Data: 26/04/2023 15:50:08

and 2017. In 2012, the maximum level of convictions under Article 178a of the Polish Criminal Code committed by women was 4,527 cases. What is still worrying is that in the years 2004-2017, the level of convictions on the basis of the analysed crime remained high, reaching or exceeding 3,000 cases per year on average.

\section{Crimes against property committed by women}

in the years 2003-2018

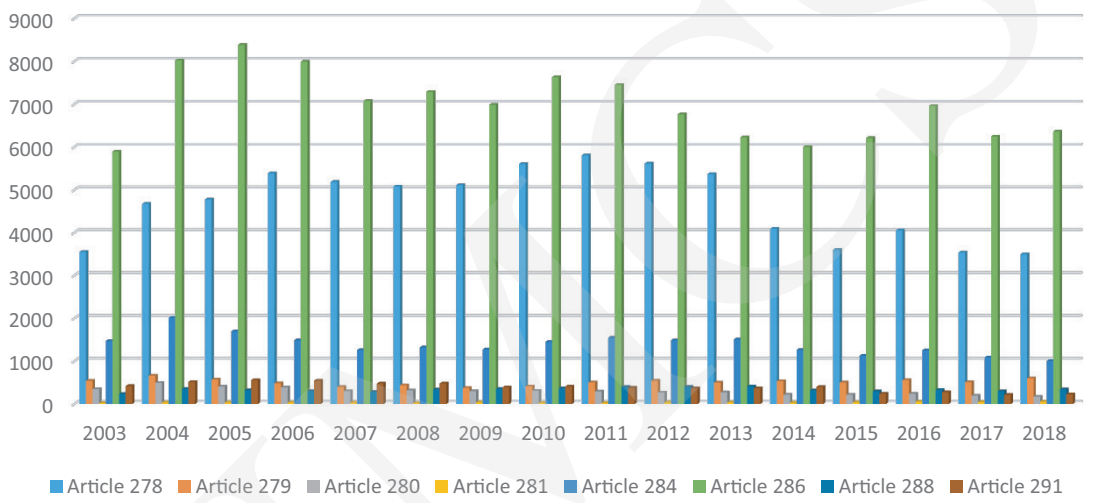

Figure 6.

Source: own elaboration based on statistical data obtained from the Ministry of Justice.

Another type of prohibited act where women lead to a breach of traffic safety is to cause a traffic accident. However, it should be clearly stated that the frequency of convictions under Article 177 of the Polish Criminal Code remains significantly lower compared to the level of convictions for the crime of driving a motor vehicle while in a state of intoxication or under the influence of a narcotic drug. ${ }^{23}$ In the period from 2004 to 2010, convictions for the crime typified in Article 177 of the Polish Criminal Code were nearly 1,100 cases per year, with the maximum level recorded in 2008 - 1272 cases. In turn, between 2011 and 2018, convictions of

${ }^{23}$ It is worth noting that the percentage of accidents caused by women compared to the total number of accidents caused by both sexes each year rises, reaching the following ceilings: $16.54 \%$ in 2006 (men 84.46\%), 17.43\% in 2007 (men 82.57\%), 18.24\% in 2008 (men 81.76\%), 19.24\% in 2009 (men 80.76\%), 19.32\% in 2010 (men 80.68\%), 20.77\% in 2011 (men $77.58 \%), 21.97 \%$ in 2012 (men 78.03\%), 22.42\% in 2013 (men 77.58\%), 22.26\% in 2014 (men $77.74 \%$ ), 22.76\% in 2015 (men $77.24 \%$ ). It seems that the progression of accidents is influenced by the increase in the number of driving licences obtained by women. At the same time, it should be stressed that, according to the calculation of the number of deaths per 100 accidents caused by both sexes, this ratio is much lower for women than for men: 5.7 in 2006 (men 11.25), 5.7 in 2007 (men 10.98), 5.87 in 2008 (men 10.75), 4.97 in 2009 (men 10.27), 4.40 in 2010 (men 10.07), 4.60 in 2011 (men 10.27), 9.86 in 2012 (men 9.86), 4.11 in 2013 (men 9.36), 4.22 in 2014 (men 8.94), 4.20 in 2015 (men 8.80). This ratio was decreasing for both sexes over the given period, but accidents caused by women remain milder with respect to the effects. Cf. E. Jurgielewicz-Delegacz, op. cit., pp. 239-241. 
Pobrane z czasopisma Studia Iuridica Lublinensia http://studiaiuridica.umcs.pl Data: 26/04/2023 15:50:08

Women as Perpetrators of Crimes in Poland: An Analysis from a Statistical Perspective

women for the crime of traffic accidents were on average 850 cases per year. What is interesting is that, from 2015 onwards, this category of crimes committed by women also includes crimes involving driving a motor vehicle without a licence (Article 180a of the Polish Criminal Code). From the perspective of statistics, the conclusion is that the level of convictions shows, unfortunately, an evolving pattern.

Crimes against traffic safety committed by women between 2003 and 2018

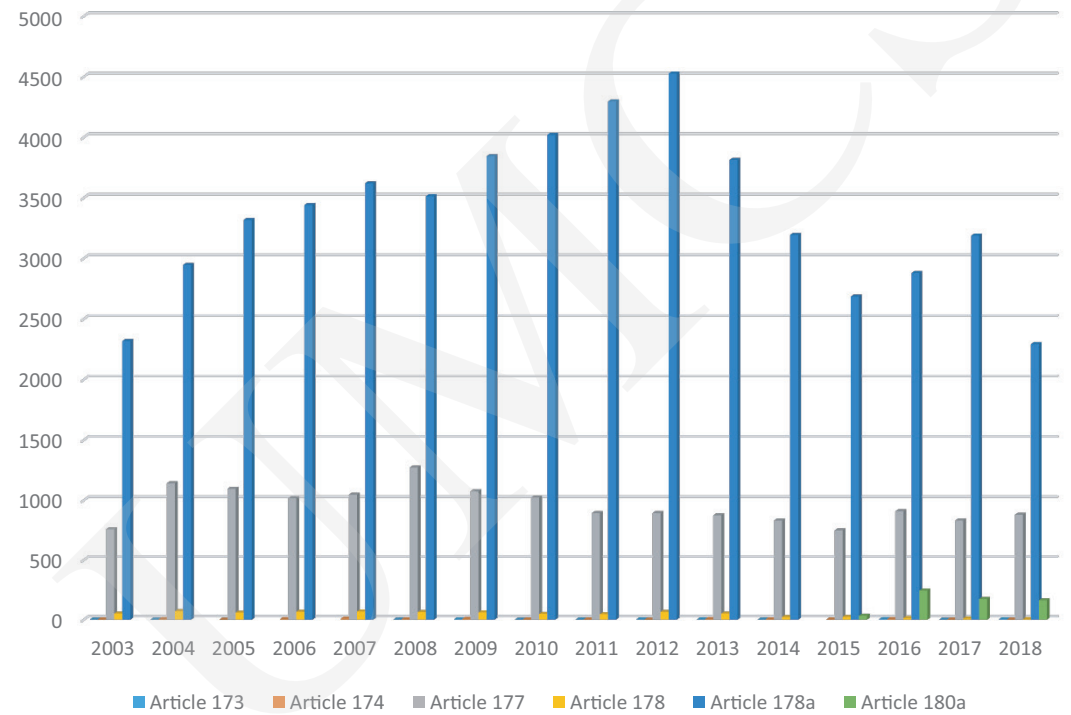

Figure 7.

Source: own elaboration based on statistical data obtained from the Ministry of Justice.

\section{CONCLUSIONS}

The research material presented in this article, in the form of a compilation of statistical data on the phenomenon of female delinquency occurring in Poland, justifies the formulation of a few essential remarks.

Firstly, the overall level of convictions of women during the presented research periods 1980-1996 (Figure 2) and 2003-2018 (Figure 1) increased significantly. While in the first research period the minimum level of convictions slightly exceeded 6,000 cases (1990) and the maximum reached 17,315 cases (1985), in the second one the level of convictions was close to 27,000 cases (2017) and the maximum oscillated around 40,000 convictions (2005). The data presented show that the overall number of female convictions at the turn of the $20^{\text {th }}$ and $21^{\text {st }}$ centuries increased significantly. Their minimum threshold in the two analysed research 
periods was 4.5 times higher (from 6,000 to 27,000 ), while the maximum level was 2.5 times higher (from 17,000 to 40,000). It should therefore be stressed that the phenomenon of female delinquency, given the number of their convictions, increased dramatically. In the first two decades of the $21^{\text {st }}$ century, female perpetrators were more criminally active than in the last two decades of the $20^{\text {th }}$ century. The second observation that results from the data presented is that the increase between the minimum and maximum levels of convictions in the periods under examination remained comparable. Thirdly, it is positive that, although the overall level of convictions of women increased in the 2000 s, compared with the trend at the end of the $20^{\text {th }}$ century, a slow, yet irregular, decrease can be indicated as regards the dominant trend for the 2003-2018 research period.

Turning here to the analysis of the different categories of crimes committed by women, it is important to note certain trends in their criminal activity. In considerations of criminology, the issue of female delinquency invariably comes up against the question of determining the direction of their criminal activities. Research obtained from the Ministry of Justice shows that women commit similar categories of crime to men. ${ }^{24}$ Only the extent of male and female delinquency remains a differentiating element. The analysis of the data presented gives rise to the conclusion that women were recorded as perpetrators of all categories of crimes, typified in the specific part of the Criminal Code, and also as perpetrators of crimes within the scope of non-code criminal law. ${ }^{25}$

${ }^{24}$ According to R. Szczepanik, the fact that women commit crimes with a high level of social harm does not mean that they display male characteristics in their behaviour. The active fulfilment of the features of crimes indicating a high level of aggression, such as robbery, indicates that the female perpetrators have perhaps not mastered ways of dealing with difficult situations, have a low level of education or a low socio-economic status. Sometimes the result of their committing serious crimes is a specific personality and psychological predisposition. See R. Szczepanik, Teoretyczne perspektywy interpretacji przestępczości kobiet i mężczyzn, [in:] Teoretyczne perspektywy badań nad edukacja rodzajowa, ed. M. Chomczyńska-Rubacha, Łódź 2007, pp. 165-166.

25 The following regulations should be mentioned among the special laws that contain crimes whose features are fulfilled by women: Article 46 of the Act of 26 January 1984 - Press Law (Journal of Laws 1984, no. 5, item 24); Article 27 para. 1 and 2 and Article 32 para. 1 of the Act of 31 January 1985 on the prevention of drug addiction (Journal of Laws 1985, no. 4, item 15); Article 12 points 1-4 of the Act of 9 November 1995 on the protection of health against the consequences of using tobacco (Journal of Laws 1996, no. 10, item 55); Article 40 para. 1-2, Article 41, Article 42 para. 1-3, Article 43 para. $1-3$, Article 44 para. 1, Article 45 para. 1-2, Article 46 para. 1-3, Article 47, Article 48 para. 1-3 and Article 49 para. 1-2 of the Act of 24 April 1997 on counteracting drug addiction (Journal of Laws 1997, no. 95, item 468); Articles 53, 55, 56, 57, 58, 59, 62 and 63 of the Act of 29 July 2005 on counteracting drug addiction (Journal of Laws 2005, no. 179, item 1485); Article 54, Article $80 \S 1$, Article $94 \S 1-2$ of the Fiscal Penal Act of 26 October 1971 (Journal of Laws 1984, no. 22, item 103); Article 57 of the Act of 31 January 1985 on trademarks (Journal of Laws 1985, no. 5, item 17); Article 27 para. 1 items 1-3 of the Act of 18 April 1985 on inland fisheries (Journal of Laws 1985, no. 21, item 91); Article 115 of the Act of 31 January 1989 - Banking Law (Journal of Laws 1989, no. 4, item 21); 
Articles 23 and 24 of the Act 16 April 1993 on combating unfair competition (Journal of Laws 1993, no. 47, item 211); Article 77 para. 1-2 and Article 79 points 1-4 of the Act of 29 September 1994 on accounting (Journal of Laws 1994, no. 121, item 591); Article 35 of the Act of 21 August 1997 on the protection of animals (Journal of Laws 1997, no. 111, item 724); Act of 10 September 1999 - Fiscal Penal Code (Journal of Laws 1999, no. 83, item 930); Act of 15 September 2000 - Code of Commercial Companies (Journal of Laws 2000, no. 94, item 1037); Article 12, Article 12a and Article 14 of the Act of 2 March 2001 on spirits, kneading and bottling spirits (Journal of Laws 2001, no. 31, item 353); Articles 49 and 50 of the Act of 11 May 2001 on the health conditions of food and nutrition (Journal of Laws 2001, no. 63, item 634); Article 191 of the Act of 18 July 2001 - Water Law (Journal of Laws 2001, no. 115, item 1229); Article 31 of the Act of 13 September 2002 on spirit drinks (Journal of Laws 2002, no. 166, item 1362); Article 43 of the Act of 26 October 1982 on upbringing in sobriety and counteracting alcoholism (Journal of Laws 1982, no. 35, item 230); Article 67 of the Act of 10 October 1991 on pharmaceuticals, medical materials, pharmacies, wholesalers and pharmaceutical supervision (Journal of Laws 1991, no. 105, item 452); Article 35 of the Act of 23 May 1991 on trade unions (Journal of Laws 1991, no. 55, item 234); Article 26 of the Act of 23 May 1991 on resolving collective disputes (Journal of Laws 1991, no. 55, item 236); Articles 116, 117 and 118 of the Act of 4 February 1994 on copyright and related rights (Journal of Laws 1994, no. 24, item 83); Articles 90-91 of the Act of 7 July 1994 - Construction Law (Journal of Laws 1994, no. 89, item 414); Article 56 of the Act of 29 June 1995 on public statistics (Journal of Laws 1995, no. 88, item 439); Articles 52 and 53 of the Act of 13 October 1995 - Hunting Law (Journal of Laws 1995, no. 147, item 713); Article 81 of the Act of 5 July 1996 on tax consultancy (Journal of Laws 1996, no. 102, item 475); Article 58 of the Act of 5 December 1996 on the medical profession (Journal of Laws 1996, no. 28, item 152); Article 166 of the Act of 21 August 1997 - Law on Public Trading in Securities (Journal of Laws 1997, no. 118, item 754); Article 51 of the Act of 24 April 1997 on combating infectious animal diseases, examination of slaughter animals and meat and on the Veterinary Inspection (Journal of Laws 1999, no. 66, item 752); Article 49 of the Act of 22 August 1997 on the protection of persons and property (Journal of Laws 1997, no. 114, item 740); Article 219 of the Act of 28 August 1997 on the organization and operation of pension funds (Journal of Laws 1997, no. 139, item 934); Article 14 of the Act of 11 September 1997 on the organization of economic activity by persons performing public functions (Journal of Laws 1997, no. 106, item 679); Articles 49, 51 and 52 of the Act of 29 August 1997 on the protection of personal data (Journal of Laws 1997, no. 133, item 883); Articles 202g and Article 202j of the Act of 16 July 1998 - Election Ordinance to municipal councils, poviats and voivodship assemblies (Journal of Laws 1998, no. 95, item 602); Articles 24 and 25 of the Act of 22 January 2000 on general product safety (Journal of Laws 2000, no. 15, item 179); Article 305 of the Act of 30 June 2000 - Industrial Property Law (Journal of Laws 2001, no. 49, item 508); Article 123 of the Act of 21 July 2000 - Telecommunications Law (Journal of Laws 2000, no. 73, item 853); Article 125 of the Act of 16 March 2001 on BOR (Journal of Laws 30 March 2001); Article 35 of the Act of 16 November 2000 on counteracting and financing terrorism (Journal of Laws 2000, no. 153, item 1505); Article 28 of the Act of 7 June 2001 on collective water supply (Journal of Laws 2001, no. 72, item 747); Article 38 of the Act of 15 December 2000 on the Trade Inspection (Journal of Laws 2001, no. 4, item 25); Article 63 of the Act of 21 December 2000 on technical inspection (Journal of Laws 2000, no. 122, item 1321); Article 37 of the Act of 22 June 2001 on the production and trade in explosives, weapons and ammunition (Journal of Laws 2001, no. 67, item 679); Articles 124 and 126 of the Act of 6 September 2001 - Pharmaceutical Law (Journal of Laws 2001, no. 126, item 1381); Articles 6 and 7 of the Act of 5 July 2002 on the protection of certain services provided by electronic means based on or consisting in conditional access (Journal of Laws 2002, no. 126, item 1068); Article 45 of the Act of 30 August 2002 on the conformity assessment system (Journal of Laws 2002, no. 204, item 208); Articles 30-32 of the Act of 13 September 2002 on spirit drinks (Journal of Laws 2002, no. 166, item 1362); Article 522 of the Act of 28 February 2003 - Bankruptcy and Rehabilitation Law (Journal of Laws 2003, no. 60, item 535); Article 109 of the Act of 23 July 2003 on 
An analysis of individual crimes committed by women in Poland against the background of the statistics presented proves that the most frequently committed crimes are those which occur in four basic categories: against property, against traffic safety, against the authenticity of documents and against business trading, the first of which has by far the highest frequency of convictions. In the years 2003-2018, nearly 243,000 women were convicted of crimes against property, while in the case of crimes against traffic safety, the total number of convicted female perpetrators reached 70,000, while in the case of crimes against the authenticity of documents, it was nearly 50,000 cases, and as regards crimes against business trading, 40,500 convicted female perpetrators were recorded. This means that the level of convictions of women for crimes against property alone radically exceeded the level of the sum of convictions for three consecutive categories of crimes with the highest degree of frequency, and remained in the ratio of 243,000 to 160,500 .

Looking at the successive types of crimes falling into their various categories, it should be noted that in the case of crimes against property, three types of prohibited acts prevailed in the activity of female perpetrators: fraud (Article 286 of the Polish Criminal Code), ${ }^{26}$ theft in the basic variety (Article 278 of the Polish Criminal Code) and misappropriation (Article 284 of the Polish Criminal Code). Bearing in mind that an average of 7,000 convictions for fraud, 4,680 convictions for theft and 1,390 convictions for misappropriation were recorded among wom-

the protection and care of monuments (Journal of Laws 2003, no. 162, item 1568); Act of 23 January 2004 on the monitoring and quality control system for liquid fuels (Journal of Laws 2004, no. 34, item 293); Articles 77 and 78 of the Act of 11 March 2004 on the protection of animals and combating infectious diseases (Journal of Laws 2004, no. 69, item 625); Article 128 of the Act of 16 April 2004 on nature protection (Journal of Laws 2004, no. 880, item 6056); Article 43 of the Act of 1 July 2005 on the collection of cells, tissues and organs (Journal of Laws 2005, no. 169, item 1411); Article 25 of the Act of 16 December 2005 on products of animal origin (Journal of Laws 2005, no. 17, item 127); Articles 96 and 97 of the Act of 25 August 2006 on food and nutrition safety (Journal of Laws 2006, no. 171, item 1225); Articles 42-44 of the Act of 18 October 2006 on the production of spirit drinks (Journal of Laws 2006, no. 208, item 1539); Article 31 of the Act of 25 August 2006 on the fuel quality monitoring and scrutinizing system (Journal of Laws 2006, no. 169, item 1200); Articles 58-60 of the Act of 20 March 2009 on the safety of mass events (Journal of Laws 2009, no. 62, item 504); Article 74 of the Act of 5 November 2009 on cooperative savings and credit unions (Journal of Laws 2012, item 855); Article 48 of the Act of 9 April 2010 on disclosing economic information and disclosing economic data (Journal of Laws 2010, no. 81, item 530); Articles 93 and 100 of the Act of 20 May 2010 on medical devices (Journal of Laws 2010, no. 107, item 679); Articles 506 and 509 of the Act of 5 January 2011 - Electoral Code (Journal of Laws 2011, no. 21, item 112); Article 176 of the Act of 9 June 2011 - Geological and Mining Law (Journal of Laws 2011, no. 163, item 981); Article 150 of the Act of 19 August 2011 on payment services (Journal of Laws 2011, no. 199, item 1175); Article 464 of the Act of 12 December 2013 on foreigners (Journal of Laws 2013, item 1650); Article 90 of the Act of 15 January 2015 on bonds (Journal of Laws 2015, item 238); Article 439 of the Act of 11 September 2015 on insurance and reinsurance activities (Journal of Laws 2015, item 1844).

26 A. Czwojda, Problematyka oszustw popetnionych przez kobiety w orzecznictwie Sadu Apelacyjnego we Wroctawiu, [in:] Przestępczość kobiet. Wybrane..., p. 128 ff. 
en each year, it should be concluded that fraud remains the most characteristic of crimes against property committed by women. Therefore, in the case of the subjective side of the analysed category of crimes, the predominant objective remains the achievement of a financial benefit or the misappropriation of someone else's movable property, so the female perpetrators aim primarily at achieving a specific material gain.

Meanwhile, in the case of crimes against traffic safety committed by the female sex, the following types of prohibited acts prevail: driving a motor vehicle while intoxicated or under the influence of narcotic drugs (Article 178a of the Polish Criminal Code) and causing a traffic accident (Article 177 of the Polish Criminal Code). The third type of a prohibited act belonging to the analysed category of crimes, namely driving a motor vehicle after the revocation of the required licence (Article 180a of the Polish Criminal Code), which has been in the statistics since 2015, remains a peculiar novelty. Between 2003 and 2018, there were 53,895 convictions under Article 178a of the Polish Criminal Code, and 14,380 convictions under Article 177 of the Polish Criminal Code. What is worrying, therefore, is that women are not prevented from driving in a state of intoxication or under the influence of a narcotic drug. Nevertheless, we should bear in mind that they are up to four times less likely to be convicted of causing a traffic accident than for driving under the influence of alcohol or a narcotic drug. It is worth pointing out that the last of the indicated types of crime has only recently begun to appear in statistical summaries, but it is supposed to be incidental in comparison with the indicated types of crime against traffic safety (between 2015 and 2018, it was only 612 convictions). But given the nature of the crimes that dominate the criminal activity of women, from the perspective of their category under consideration, it must be said that, unfortunately, they show an advanced tendency to violate and disregard the precautionary rules that apply to road traffic. On the other hand, a positive trend starting in 2013 remains noticeable, although irregular, decrease in convictions under Article 178a of the Polish Criminal Code.

Several important observations also arise in connection with the analysis of the crimes committed by female perpetrators which show the highest degree of social harm and affect the life and health of individuals. Firstly, the dominant types of prohibited acts in this category of crimes are: brawl and beating (Article 158 of the Polish Criminal Code) as well as medium and slight damage to health (Article 157 of the Polish Criminal Code). In total, between 2003 and 2018, there were 6,875 convictions for brawls and beatings committed by women and 6,000 convictions under Article 157 of the Polish Criminal Code. Unfortunately, the dominance of the types of prohibited acts indicated in the category of crimes under examination demonstrates a clear increase in aggression among women ${ }^{27}$ who decide to commit

${ }^{27}$ A. Frodi, J. Macaulay, P.R. Thome, Are women always less aggressive than men? A review of the experimental literature, "Psychological Bulletin" 1977, vol. 84(4), pp. 634-660. 
them. There is no doubt that a positive trend can be found in the slow downward evolution of the crime of murder of the basic type. In the analysed period, the maximum threshold of convictions under Article $148 \S 1$ of the Polish Criminal Code was 78 cases (in 2003) and the minimum was 28 cases (in 2018). A total of 878 convictions under Article $148 \S 1$ of the Polish Criminal Code were recorded in the analysed period, with convictions for murder of aggravated types being incidental.

However, undoubtedly the most interesting conclusions are drawn from a closer analysis of the number of convictions, which is a manifestation of exclusively female criminal activity, the crime of infanticide. It should be stated that, given the level of convictions, the type of prohibited act analysed in the years 2003-2012 showed a disappearing character, with a frequency of between 6 and 16 convictions per year, with one conviction per year already occurring incidentally from 2013 onwards, and then disappearing from the statistical summary in 2017. We can therefore put forward a thesis that infanticide remains a strongly declining crime, and that convictions under Article 149 of the Polish Criminal Code currently occur incidentally or not at all in the statistics. This means that the crime under investigation cannot continue to be regarded as the only, most symptomatic female crime because, according to the statistical analysis, from the perspective of decisions made by law enforcement agencies, there were only 6 convictions between 2013 and 2018, proving the fulfilment of its features by women.

The analysis of the other categories of crimes of which women remain the perpetrators also draws interesting conclusions. Despite the fact that the female sex is associated, above all, with particular predispositions for the care and protection of the offspring and loved ones, as well as with the ability to secure the proper functioning of the family, the paradoxically high level of convictions of women in the category of crimes against the family and guardianship (14,000 cases over a period of 16 years), especially several hundred cases of convictions per year relating to the fulfilment of the features of the crime of abuse, remains worrying. It should be stressed that the statistical research presented also refutes the belief, which is well established in the social awareness, that there are categories of crimes reserved exclusively for men, the most symptomatic of which are crimes against sexual freedom and decency. We should remember that although the frequency of convictions of women on the basis of crimes in this category remains low, they undertake a number of criminal behaviours against sexual freedom and decency, and the dominant types of crimes committed by female perpetrators in this category are procurement, pimping and facilitation of prostitution (Article $204 \S \S 1$ and 2 of the Polish Criminal Code) ${ }^{28}$

${ }^{28}$ Cf. A. Więcek-Durańska, Kobiety jako sprawczynie zgwałceń ze szczególnym okrucieństwem, „Psychiatria Polska” 2019, no. 153, pp. 1-18; www.psychiatriapolska.pl; R. Fluder, Karnoprawna ocena realizacji przez kobietę znamion art. 197 k.k., [in:] Przestępczość kobiet. Wybrane..., p. 150 ff.; 
When analysing the phenomenon of female delinquency, it should also be pointed out that the economic transformation in Poland over the last two decades has been reflected in the increase in the proportion of female perpetrators in economic crime and the associated increase in convictions in this category. For it should be recalled that this is the fourth group of crimes committed by women with the highest degree of frequency. It can therefore be concluded that the increase in the level of education of female perpetrators, as well as their clear, especially in the last decade, activity in the labour market not only contributes to positive changes in the social structure, but also provides a basis for the acquisition of skills in exceeding established standards, including at a normative level. Moreover, it is worth specifying that in the case of crimes against business trading committed by women, convictions for the crime of first-party fraud (Article 297 of the Polish Criminal Code) and thwarting or depleting the satisfaction of their creditor (Article $300 \S 2$ of the Polish Criminal Code) prevail. These categories of crimes clearly show that women can pursue them with quite a bit of freedom, given their frequent employment in various financial institutions (e.g. banks).

In conclusion, a rather controversial thesis should be put forward concerning the identification of a crime which currently remains the most symptomatic for women in Poland. The clear change in the level of education of the female sex in favour of significant self-development, the subsequent development of women's professional opportunities and competences, as well as their rising level of earnings, have resulted in the stereotypical nature of female delinquency - infanticide losing this status. In view of the statistical statements presented in this study, it should be stated that the crime which implied the highest level of convictions among women in Poland between 2003 and 2018 was fraud. Therefore, it is worth stressing that over the last two decades, there has been a very clear change in the criminal activity of a female perpetrator, who will now most often concentrate on committing crimes against property. Many years ago, J. Błachut stressed in the context of research into female delinquency that "It also makes little sense to ask why women commit crimes. Being a kind of behaviour, a criminal act is possible for both a man and a woman. And it would be strange if women did not act in this way at all". ${ }^{29}$ It would be all the more strange if, with the development of all levels of their existence (education, work, material or social status), the level of criminal activity were not to be further transformed.

\footnotetext{
A. Siemaszko, B. Gruszczyńska, M. Marczewski, Atlas przestępczości w Polsce 3, Warszawa 2003; L.M. Williams, D. Finkelhor, The characteristics of incestuius fathers. A review of recent studies, [in:] Handbook of Sexual Assault: Issues, Theories and Treatment of the Offender, eds. W. Marshall, D. Laws, H. Barbarce, New York - London 1990, pp. 231-255.

29 J. Błachut, Kobiety recydywistki..., pp. 47-48.
} 


\section{REFERENCES}

\section{Literature}

Adler F., The interaction between women's emancipations and female criminality: A cross-cultural perspective, [in:] The Criminology of Deviant Women, eds. F. Adler, R.J. Simon, Boston 1979.

Bałandynowicz A., Przestępczość kobiet w środowisku miejskim, „Prokuratura i Prawo” 2002, no. 10.

Błachut J., Kobiety recydywistki w świetle badań kryminologicznych, Wrocław 1981.

Błachut J., Płeć a przestępczość, [in:] Nauka wobec przestępczości. Księga ku czci Prof. T. Hanauska, eds. J. Błachut, M. Szewczyk, J. Wójcikiewicz, Kraków 2001.

Błachut J., Gaberle A., Krajewski K., Kryminologia, Gdańsk 2004.

Brzezińska J., Dzieciobójstwo. Aspekty prawne i etyczne, Warszawa 2013.

Brzezińska J., O dzieciobójstwie z perspektywy statystyk, „Nowa Kodyfikacja Prawa Karnego” 2010, no. 26.

Brzezińska J., O niektórych kontrowersjach wokół znamion przestępstwa dzieciobójstwa, „Ius Novum" 2012, no. 2.

Budyn-Kulik M., Zabójstwo tyrana domowego. Studium prawnokarne i wiktymologiczne, Lublin 2005.

Cabalski M., Ogólne problemy stosowania przemocy przez kobiety, „Studia Prawnicze i Administracyjne Wyższej Szkoły Menedżerskiej w Warszawie” 2011, no. 1.

Cabalski M., Przemoc stosowana przez kobiety, Kraków 2017.

Carrabine E., Iganski P., Lee M., Criminology: A Sociological Introduction, New York 2004.

Choy O., Raine A., Venables P.H., Farrington D.P., Explaining the gender gap in crime: The role of heart rate, "Criminology" 2017, vol. 55(2), DOI: https://doi.org/10.1111/1745-9125.12138.

Czwojda A., Problematyka oszustw popetnionych przez kobiety w orzecznictwie Sadu Apelacyjnego we Wrocławiu, [in:] Przestępczość kobiet. Wybrane aspekty, eds. J. Brzezińska, Warszawa 2017.

Florkowski A., Telesiński S., Ocena psychopatologiczna sprawców zabójstw związanych z konfliktami w rodzinie, [in:] Stany afektywne w opiniowaniu sadowym psychiatryczno-psychologicznym, eds. Z. Majchrzyk, T. Gordon, E. Milewska, Warszawa 1991.

Fluder R., Karnoprawna ocena realizacji przez kobietę znamion art. 197 k.k., [in:] Przestępczość kobiet. Wybrane aspekty, ed. J. Brzezińska, Warszawa 2017.

Frodi A., Macaulay J., Thome P.R., Are women always less aggressive than men? A review of the experimental literature, "Psychological Bulletin" 1977, vol. 84(4),

DOI: https://doi.org/10.1037/0033-2909.84.4.634.

Grzyb M., Habzda-Siwek E., Pteć a przestępczość. O problemie dysproporcji płci wśród sprawców przestępstw z użyciem przemocy, „Archiwum Kryminologii” 2013, vol. 35.

Hołyst B., Kryminologia, Warszawa 2004.

Hołyst B., Psychologia kryminalistyczna, Warszawa 2006.

Jaśkiewicz-Obydzińska T., Wach E., Sprawczynie zabójstw, [in:] Zabójcy i ich ofiary. Psychologiczne podstawy profilowania nieznanych sprawców zabójstw, eds. J.K. Gierowski, T. Jaśkiewicz-Obydzińska, Kraków 2002.

Jurgielewicz-Delegacz E., Wypadki w komunikacji powodowane przez kobiety będace kierowcamiujęcie kryminologiczne, [in:] Przestępczość kobiet. Wybrane aspekty, eds. J. Brzezińska, Warszawa 2017.

Kolarczyk T., Kubiak J.R., Wierzbicki P., Przestępczość kobiet. Aspekty kryminologiczne i penitencjarne, Warszawa 1984.

Kołakowska-Przełomiec H., Przemoc w rodzinie, „Ruch Prawniczy, Ekonomiczny i Socjologiczny” 1985, no. 1 . 
Krajewski K., O pojęciu przemocy w kryminologii, „Studia Kryminologiczne, Kryminalistyczne i Penitencjarne" 1988, no. 19.

Majchrzyk Z., Kiedy kobieta zabija. Motywy, osobowość, relacja sprawca-ofiara, strategie obronne, Warszawa 2009.

Majchrzyk Z., Zabójczynie i zabójcy, Warszawa 2008.

Makara-Studzińska M., Grzywa A., Turek R., Kobiece oblicza stosowania przemocy, „Postępy Psychiatrii i Neurologii" 2005, no. 14.

Mandal E., Kobiecość i męskość. Popularne opinie a badania naukowe, Warszawa 2003.

McQuigg R.J.A., Potential problems for the effectiveness of international human rights law as regards domestic violence, [in:] International Human Rights Law and Domestic Violence: The Effectiveness of International Human Rights Law, ed. R.J.A. McQuigg, Oxford - New York 2011.

Mielnik S., Mężczyzna jako ofiara przemocy w rodzinie, [in:] Mężczyzna w kryzysie. Sytuacja prawna mężczyzn przė̇ywających problemy rodzinne, ed. R. Kucharski, Warszawa 2008.

Moir A., Jessel D., Pteć mózgu. O prawdziwej różnicy między mężczyzna a kobieta, Warszawa 2017.

Pełka-Sługocka M.-D., Sługocki L., Przestępstwa przy użyciu przemocy popetnione przez kobiety w Polsce, „Studia Kryminologiczne, Kryminalistyczne i Penitencjarne” 1983, vol. 13.

Przybysz-Zaremba M., (Prze)moc kobiet - (nie)moc mężczyzn, „Szkice Humanistyczne Olsztyńskiej Szkoły Wyższej” 2008, vol. 8.

Siemaszko A., Gruszczyńska B., Marczewski M., Atlas przestępczości w Polsce 3, Warszawa 2003.

Steffensmeier D., Allan E., Gender and Crime: Toward a Gendered Theory of Female Offending, "Annual Review of Sociology" 1996, vol. 22, DOI: https://doi.org/10.1146/annurev.soc.22.1.459.

Szatner S., Socjologia kobiety, Warszawa 1948.

Szczepanik R., Teoretyczne perspektywy interpretacji przestępczości kobiet i mężczyzn, [in:] Teoretyczne perspektywy badań nad edukacją rodzajowa, ed. M. Chomczyńska-Rubacha, Łódź 2007.

Tyszkiewicz L., Kryminologia. Zarys systemu, Katowice 1986.

Walker J.T., Maddan S., Understanding Statistics for the Social Sciences, Criminal Justice, and Criminology, London 2013.

Więcek-Durańska A., Kobiety jako sprawczynie zgwałceń ze szczególnym okrucieństwem, „Psychiatria Polska" 2019, no. 153.

Williams L.M., Finkelhor D., The characteristics of incestuius fathers. A review of recent studies, [in:] Handbook of Sexual Assault: Issues, Theories and Treatment of the Offender, eds. W. Marshall, D. Laws, H. Barbarce, New York - London 1990.

Zielińska E., Kobiety i wymiar sprawiedliwości, „Prawo i Płeć” 2001, no. 1.

\section{Netography}

Diagnoza zjawiska przemocy w rodzinie w Polsce wobec kobiet $i$ wobec mężczyzn. Cześć I: Raport z badań ogólnopolskich, https://archiwum.mpips.gov.pl/gfx/mpips/userfiles/_public/1-2010_\%20 Raport-ogolnopolski_K-M_01-03-11.pdf [access: 10.10.2020].

Otto P., Płeć piękna także łamie prawo. Odsetek kobiet wśród sprawców przestępstw rośnie, 8.01.2019, https://prawo.gazetaprawna.pl/galerie/1390926,duze-zdjecie,2,odsetek-kobiet-wsrod-sprawcow-przestepstw-rosnie.html [access: 19.11.2020].

Stojer-Polańska J., Ciemna strona kobiet, www.swps.pl/strefa-psyche/blog/relacje/16043-ciemna-strona-kobiet [access: 19.11.2020]. 


\section{Legal acts}

Fiscal Penal Act of 26 October 1971 (Journal of Laws 1984, no. 22, item 103).

Act of 26 October 1982 on upbringing in sobriety and counteracting alcoholism (Journal of Laws 1982, no. 35, item 230).

Act of 26 January 1984 - Press Law (Journal of Laws 1984, no. 5, item 24).

Act of 31 January 1985 on the prevention of drug addiction (Journal of Laws 1985, no. 4, item 15).

Act of 31 January 1985 on trademarks (Journal of Laws 1985, no. 5, item 17).

Act of 18 April 1985 on inland fisheries (Journal of Laws 1985, no. 21, item 91).

Act of 31 January 1989 - Banking Law (Journal of Laws 1989, no. 4, item 21).

Act of 23 May 1991 on resolving collective disputes (Journal of Laws 1991, no. 55, item 236).

Act of 23 May 1991 on trade unions (Journal of Laws 1991, no. 55, item 234).

Act of 10 October 1991 on pharmaceuticals, medical materials, pharmacies, wholesalers and pharmaceutical supervision (Journal of Laws 1991, no. 105, item 452).

Act of 16 April 1993 on combating unfair competition (Journal of Laws 1993, no. 47, item 211).

Act of 4 February 1994 on copyright and related rights (Journal of Laws 1994, no. 24, item 83).

Act of 7 July 1994 - Construction Law (Journal of Laws 1994, no. 89, item 414).

Act of 29 September 1994 on accounting (Journal of Laws 1994, no. 121, item 591).

Act of 29 June 1995 on public statistics (Journal of Laws 1995, no. 88, item 439).

Act of 13 October 1995 - Hunting Law (Journal of Laws 1995, no. 147, item 713).

Act of 9 November 1995 on the protection of health against the consequences of using tobacco (Journal of Laws 1996, no. 10, item 55).

Act of 5 July 1996 on tax consultancy (Journal of Laws 1996, no. 102, item 475).

Act of 5 December 1996 on the medical profession (Journal of Laws 1996, no. 28, item 152).

Act of 24 April 1997 on combating infectious animal diseases, examination of slaughter animals and meat and on the Veterinary Inspection (Journal of Laws 1999, no. 66, item 752).

Act of 24 April 1997 on counteracting drug addiction (Journal of Laws 1997, no. 95, item 468).

Act of 21 August 1997 - Law on Public Trading in Securities (Journal of Laws 1997, no. 118, item 754).

Act of 21 August 1997 on the protection of animals (Journal of Laws 1997, no. 111, item 724).

Act of 29 August 1997 on the protection of personal data (Journal of Laws 1997, no. 133, item 883).

Act of 22 August 1997 on the protection of persons and property (Journal of Laws 1997, no. 114, item 740).

Act of 28 August 1997 on the organization and operation of pension funds (Journal of Laws 1997, no. 139 , item 934).

Act of 11 September 1997 on the organization of economic activity by persons performing public functions (Journal of Laws 1997, no. 106, item 679).

Act of 16 July 1998 - Election Ordinance to municipal councils, poviats and voivodship assemblies (Journal of Laws 1998, no. 95, item 602).

Act of 10 September 1999 - Fiscal Penal Code (Journal of Laws 1999, no. 83, item 930).

Act of 22 January 2000 on general product safety (Journal of Laws 2000, no. 15, item 179).

Act of 30 June 2000 - Industrial Property Law (Journal of Laws 2001, no. 49, item 508).

Act of 21 July 2000 - Telecommunications Law (Journal of Laws 2000, no. 73, item 853).

Act of 15 September 2000 - Code of Commercial Companies (Journal of Laws 2000, no. 94, item 1037).

Act of 16 November 2000 on counteracting and financing terrorism (Journal of Laws 2000, no. 153, item 1505).

Act of 15 December 2000 on the Trade Inspection (Journal of Laws 2001, no. 4, item 25), 
Act of 21 December 2000 on technical inspection (Journal of Laws 2000, no. 122, item 1321).

Act of 2 March 2001 on spirits, kneading and bottling spirits (Journal of Laws 2001, no. 31, item 353). Act of 16 March 2001 on BOR (Journal of Laws 30 March 2001).

Act of 11 May 2001 on the health conditions of food and nutrition (Journal of Laws 2001, no. 63, item 634).

Act of 7 June 2001 on collective water supply (Journal of Laws 2001, no. 72, item 747).

Act of 22 June 2001 on the production and trade in explosives, weapons and ammunition (Journal of Laws 2001, no. 67, item 679).

Act of 18 July 2001 - Water Law (Journal of Laws 2001, no. 115, item 1229).

Act of 6 September 2001 - Pharmaceutical Law (Journal of Laws 2001, no. 126, item 1381).

Act of 5 July 2002 on the protection of certain services provided by electronic means based on or consisting in conditional access (Journal of Laws 2002, no. 126, item 1068).

Act of 30 August 2002 on the conformity assessment system (Journal of Laws 2002, no. 204, item 208).

Act of 13 September 2002 on spirit drinks (Journal of Laws 2002, no. 166, item 1362).

Act of 28 February 2003 - Bankruptcy and Rehabilitation Law (Journal of Laws 2003, no. 60, item $535)$.

Act of 23 July 2003 on the protection and care of monuments (Journal of Laws 2003, no. 162, item 1568).

Act of 23 January 2004 on the monitoring and quality control system for liquid fuels (Journal of Laws 2004, no. 34, item 293).

Act of 11 March 2004 on the protection of animals and combating infectious diseases (Journal of Laws 2004, no. 69, item 625).

Act of 16 April 2004 on nature protection (Journal of Laws 2004, no. 880, item 6056).

Act of 1 July 2005 on the collection of cells, tissues and organs (Journal of Laws 2005, no. 169, item 1411).

Act of 29 July 2005 on counteracting drug addiction (Journal of Laws 2005, no. 179, item 1485).

Act of 16 December 2005 on products of animal origin (Journal of Laws 2005, no. 17, item 127).

Act of 25 August 2006 on food and nutrition safety (Journal of Laws 2006, no. 171, item 1225).

Act of 25 August 2006 on the fuel quality monitoring and scrutinizing system (Journal of Laws 2006, no. 169 , item 1200).

Act of 18 October 2006 on the production of spirit drinks (Journal of Laws 2006, no. 208, item 1539).

Act of 20 March 2009 on the safety of mass events (Journal of Laws 2009, no. 62, item 504).

Act of 5 November 2009 on cooperative savings and credit unions (Journal of Laws 2012, item 855).

Act of 9 April 2010 on disclosing economic information and disclosing economic data (Journal of Laws 2010, no. 81, item 530).

Act of 20 May 2010 on medical devices (Journal of Laws 2010, no. 107, item 679).

Act of 5 January 2011 - Electoral Code (Journal of Laws 2011, no. 21, item 112).

Act of 9 June 2011 - Geological and Mining Law (Journal of Laws 2011, no. 163, item 981).

Act of 19 August 2011 on payment services (Journal of Laws 2011, no. 199, item 1175).

Act of 12 December 2013 on foreigners (Journal of Laws 2013, item 1650).

Act of 15 January 2015 on bonds (Journal of Laws 2015, item 238).

Act of 11 September 2015 on insurance and reinsurance activities (Journal of Laws 2015, item 1844). 
Pobrane z czasopisma Studia Iuridica Lublinensia http://studiaiuridica.umes.pl Data: 26/04/2023 15:50:08

\begin{abstract}
ABSTRAKT
Celem niniejszego artykułu jest określenie tendencji dotyczących zjawiska przestępczości kobiet, kształtujących się w Polsce w latach 2003-2018. W tym celu na podstawie danych statystycznych uzyskanych z Ministerstwa Sprawiedliwości: 1) określono ogólną liczbę skazań sprawczyń w badanym okresie; 2) wyodrębniono te kategorie przestępstw, które skutkowały najwyższym poziomem skazań kobiet sprawczyń; 3) przeanalizowano typy przestępstw, które dominowały w kryminalnej aktywności kobiet; 4) ustalono, czy wzrasta poziom kobiecej agresji towarzyszący realizacji przestępstw. W toku badań sformułowano kilka uwag. Najważniejsze z nich są następujące: 1) kobiety dopuszczają się przestępstw analogicznych jak mężczyźni (brak takich czynów zabronionych, których by nie popełniały); 2) dzieciobójstwo, które uznawano za najbardziej symptomatyczne przestępstwo kobiece, ze względu na incydentalność skazań na podstawie art. 149 Kodeksu karnego traci ten charakter; 3) z badań statystycznych dotyczących liczby skazań kobiet sprawczyń wynika, że przestępstwem dominującym jest obecnie oszustwo.
\end{abstract}

Słowa kluczowe: przestępczość kobiet; poziom skazań kobiet sprawczyń; dzieciobójstwo; oszustwo 